\title{
Librarians as Enemies of Books??
}

\section{Thomas R. Adams}

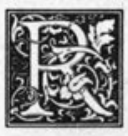

andolph G. Adams was never accused of being dull. Brash, impudent, and rambunctious, yes. He loved to create excitement, or, to use his phrase, "stir up the animals." He enjoyed the success of "Librarians as Enemies of Books," and the notoriety the five reprints brought to him. ${ }^{2}$ He wrote it in the spirit of the old story of the mule skinner who hit his most intelligent and docile mule over the head with a two-by-four to get its attention. Choosing five themes he, briefly and with a broad brush, highlighted certain library practices and trends that had become of increasing concern to lovers of the book everywhere. It was not a diatribe on the spur of the moment, as indicated by the authorities he cited from Gustave Flaubert to Louis Round Wilson. ${ }^{3}$ Indeed, Adams makes it clear that the idea came from Victor Hugo Paltsits, Keeper of Manuscripts at the New York Public Library. The continued, if dubious, place the essay occupies in library literature suggests that it said some things that some people wanted to hear. But did it really make any difference? Is the status of the book any different than it was forty-six years ago? I should like to offer a response to these questions.

Recently, important segments of the library profession have become concerned with the matter of "The Book." Deterioration of paper has made conservation a buzzword. The rising prices of antiquarian books have created a new bureaucratic term-deaccessioning. The increasing importance of electronics in recording, stor- ing, manipulating, and presenting data is seen as posing a threat to the existence of the very thing from which librarianship takes its name. The plight of the book is being addressed from the points of view of the librarian who administers them, the curator who cares for them, the printer who makes them, the publisher who promotes them, the bookseller who distributes them, the collector who treasures them, the trustee responsible for the institution that houses them, and, last but not least, the author who writes them and the reader who uses them. Each, to varying degrees, has expressed views about the dilemma: what should we be doing about the book in our changing world? There is, however, one constituency, if I may call it that, that has not been heard from (the one which both William Blades in Enemies of Books and my father were talking about), that is, the book itself, a physical object vulnerable to hazards and mistreatment. ${ }^{4}$ It is from this point of view that I propose to approach my subject. To do so I shall be talking about how books relate to librarians and to libraries. By looking at the way in which books have functioned within the framework of American librarianship, I hope to point up the way in which administrative practices have responded to the needs of the book.

Photography is taken for granted today as a normal part of the life of a library. First used in the making of books in the 1840s, it was not until the 1930s that microphotography became a viable force in library affairs. In the 1950s electrostatic printing carried it one step further, reducing the

Thomas R. Adams is John Hay professor of bibliography and university bibliographer, Brown University. This paper was read at the ACRL Rare Books and Manuscripts Section meeting on July 2, 1983. 
processing of reproduction from hours or days to seconds. This history is so familiar that there is a tendency to forget its impact on the relationship between the book and librarians. For years the information contained in a book and the book itself were treated as inseparable. That unity has now been shattered, and in the process something fundamental in the librarian's responsibilities has emerged in full view. The primary concern is for information, it is that which has first claim on the librarian's administrative and management abilities. As long as information and books were embodied in the same object, books received the full benefit of the librarian's attention. Today that is not necessarily true. To understand change rationally and accept it emotionally are different things. It takes time to fully realize that old assumptions have lost their validity. With librarians this has been particularly difficult because it was a feeling for books that drew so many of them to the profession in the first place. Management skills, costeffectiveness, an acute awareness of the bottom line are now major considerations. Anything that distracts from filling the needs of the users in the most efficient way possible becomes an amenity, acceptable only so long as it does not interfere with the principal business at hand. Among the amenities is the librarian's feeling for books.

The realities are, needless to say, a good deal different from that rather stark description of how library policy operates. For one thing, in the foreseeable future books will still be the most effective vehicle for transmitting certain kinds of information. For another, few librarians are all head and no heart. They are as susceptible to the appearance of the printed page as anybody else. The point is that when the librarian is, in a military sense, "On Duty," professional responsibilities require that information receive first priority and that the book, if necessary, be sacrificed. It is important to recognize this revolutionary development that separated the book from the text it contained if we are to understand what is happening to rare books and those who are devoting their careers to them.
Lying at the bottom of the complex structure that makes up the relation of books to libraries is the first event in that relationship, the acquisition of the book. Or, more to the point, why one book was acquired rather than another. For present purposes the motivations that lead libraries to build a particular kind of collection can be divided into three groups: libraries attempting to fill all the needs of everyone in a particular geographical area-normally the free public library; libraries devoted to filling the needs of a self-selected part of society-in its most developed form, the university research library; and libraries devoted to collecting a particular subject or subjects-in its earliest form, the historical society. In practice, these three overlap and the picture is further blurred by a fourth element: private collectors who acquire books for their own satisfaction. Rough as these divisions may be, they will help focus attention on the basic element in the relationship, the reason why books are gotten in the first place.

The youngest of the three groups is the free public library, with its evangelical zeal to serve all the needs of the community. The older tradition of the private circulating library was deemed undemocratic and outside the mainstream of American librarianship. A library dedicated to everyone should make its books available to everyone. But books are among the most cantankerous objects created by man. There are always some that refuse to fit even the most generously conceived scheme. From the beginning, public librarians violated their own canons and locked up certain books out of the reach of the normal reader. They included naughty books, expensive books, books prone to mutilation, even books that the librarian, personally, could not bear to see damaged by indiscriminate circulation, and, finally, material that was awkward to store. Thus, at the start there were exceptions, and exceptions are awkward things in something as structured as a library. These exceptions increased in size until they began to present a special problem and they began to be called collections. On top of these exceptions were the demands of what we would call "special-interest 
groups," i.e., a small minority of the community who wanted the library to make an extra effort to fulfill their special needs (e.g., business interests) and did not want to go to the expense of creating their own reference collection. This was further complicated by the private collector seeking a permanent resting place for the results of his work, usually with restrictions. The addition of these things to the operation of public libraries sometimes masks the fact that the basic need to serve the ordinary user remained unchanged. Except in places like the New York Public Library, which began with important collections, special collections emerged late in public libraries and sometimes grudgingly, unless, of course, special funding was available.

The first libraries that addressed themselves to a self-selected social group were the eighteenth-century college libraries. Their purpose was to fill the needs of an elite group, the faculty and students. Until the end of the nineteenth century, their function was to respond to what was taught in the college. This function began to expand when the faculty added to their teaching the responsibility for scholarly research. The emergence of scholarship as a recognized profession and the growth of graduate education pushed libraries to add books to meet these new needs. In the early days, scholars concentrated on the study of history, in its largest sense. The libraries responded as best they could by getting books on the subjects on which the faculty was currently working. In the case of European history, this was not always easy, so some faculty members formed seminar collections, many of which later went to their university. Withal, the acquiring of books was still a response to specific needs. The next step came when American scholars had the experience of mining the great collections in the older libraries of Europe. Here were books that inspired inquiry into hitherto unsuspected aspects of history. With the optimism and self-confidence of the nineteenth century, Americans began to try to create the same thing by buying books on a large scale, books for which there was no immediate need but which stimulated scholarship. The most notable achievement was what Archibald Cary Coolidge did for the Harvard College Library. One result was that Harvard (and other universities like it) became a national resource in addition to being a local one. This became notably apparent when scholars from all over the country began to spend their sabbaticals in Cambridge. An interesting aspect of Coolidge's approach was that he used the term special collection to describe subject collections as they stood on the shelves. Treasure room was used for the place where books were locked away. Compared to public libraries, this department emerged fairly early. The earliest rare book collection recorded is at the University of Michigan in 1899. The elitism of scholarship soon attracted private collectors, particularly those who, with ample resources, knowledge, and dedication, had built collections of distinction. The creation of rare book collections in university libraries did not demand the same kind of compromise with basic purpose required in public libraries. But they did not change that basic purpose-serving the needs of the faculty and students. One need look no further than the restrictions frequently placed on the use of a university library by those outside the university. It is worth noting however, that these restrictions are, in some cases, not applied or are relaxed for the rare book collection, a recognition of the obligation such collections have to scholarship as a whole.

Libraries concentrating on a subject or subjects took their earliest form in historical societies. Working on the assumption that until the sources have been assembled the historian cannot do his work, these societies collected as much original material as possible. In addition to books, there were manuscripts, archaeological artifacts, paintings, prints, maps, furniture, household goods, or any other object that could help illuminate the past. Ostensibly this was done in the name of the society, but it was in fact done because of the needs of the subject and was intended for the use of those working in the field. Unlike the public library or the university library, scholars had no inherent right to use the collections. They were guests of 
the society. Out of this early form, there evolved other libraries and collections whose primary concern was one or more subjects. Some were the work of private collectors such as the Pierpont Morgan Library. Others, such as the Houghton Library, were created by taking existing collections and accumulations and molding them into a coherent whole offering outstanding research opportunities. Still others were older libraries with rich collections that, like the Library Company of Philadelphia, having outlived their original purpose, turned themselves into research libraries. The corporate form can vary all the way from complete autonomy, as in the case of the Henry E. Huntington Library, through a semiautonomous association with an institution, as is the case with the John Carter Brown Library, to being an integral part of the library system, as with the Lilly at Indiana. The subjects they embrace can be restricted, such as books printed in the United States before 1786 (the American Antiquarian Society) or as broad as all the humanities (the Newberry Library). Varied as the origin, organization, and fields of collecting may be, all have one thing in common. They collect originals. Facsimiles and reprints are present, but they are clearly understood to be unsatisfactory substitutes that do not foreclose obtaining the original if the opportunity presents itself.

The role of the private collector has been to strengthen and increase the ability of libraries and collections to provide resources for original research. Some do so by adding to already existing fine collections, as Albert E. Lownes did when his books on natural history were added to Brown University's already excellent collections on the history of mathematics and the physical sciences. Others stimulate work in neglected fields, as did James Ford Bell for the early history of commerce in the collection that bears his name at Minnesota. Fellowship programs and publication programs are the usual expression of the desire to see a collection expand scholarly activity. On the other hand, private collectors have not been willing to entrust the results of their work to the service-oriented philosophy of li- brarianship. They are frequently hedged about by restrictive conditions to protect their books from indiscriminate use or loss of identity. Finally, like historical societies, the private collector acquires books as objects, so it is not surprising that steps are taken to protect them.

In this country, then, we have two distinct basic library policies. The dominant one is to collect books (and today, other media) for the purpose of bringing together information so that it can be organized, ready for a summons from the constituency being served. The role is fundamentally a passive one: ready to answer questions. The other kind of libraries have no constituencies as such. They address themselves to abstract subjects or themes. They acquire books to ask questions.

The status of those who run rare book collections is as varied as the organization and contents of the collections themselves. However, the existence for almost twenty-five years of ACRL's Rare Book and Manuscript Section indicates that things are better than they were forty-six years ago when the group was made up of a few entrepreneurs who scorned the American Library Association and did business over three-martini lunches at Longchamps in New York. ${ }^{6}$ We are all conscious of the growing interest among scholars in books, as indicated by your 1980 conference, "Books and Society in History." We have long been aware of the growing attention being paid to books as aesthetic objects, significant because of their design and craftsmanship; and we all somehow sense that as a monument to a major achievement in Western civilization, books are growing to have a symbolic value in their own right. Yet our individual careers could not be more diverse.

At this meeting it would be perfectly possible for an authority on fifteenthcentury typefaces to be sitting next to an expert on the deterioration of nineteenthcentury paper, or a cataloger next to an archivist who isn't a librarian at all. Some curators draw attention to their collection; others do so by a kind of glorified "show and tell" designed to draw attention to the needs of the whole library. Control over 
what is added to the collection may be in the hands of the staff or those decisions may be made outside the collection. The head of the collection's place in the table of organization can be anywhere from near the top to well down toward the bottom. Some head librarians are enthusiastic about rare books; others find them a bother inherited from the past and wish they would go away. All of us feel that we have something in common; but it isn't necessarily librarianship.

One is reminded of George Bernard Shaw's quip about England and America being two countries separated by a common language. Patron is used among librarians for people who use the library. Rare book people use it for people who support the library. Use is a positive word indicating the ultimate objective, or it is a negative word connoting wear and tear. Conservation includes microfilming, and then throwing away the original, which is, of course, destruction. The word edition means something different to someone working with AACR2 cataloging rules than to someone working with the guidelines of Gregg, McKerrow, and Bowers. Subject is a category into which books are fitted for cataloging purposes; in rare book collections, it is the topic being explored by someone doing research in an area for which no categories yet exist. Cooperation to a rare book person means to be "coopted"; the preferred term is coordinate, with the implication of working together as peers. I'm sure all of you can think of other situations where on the surface we appear to be doing the same things, but in fact are doing them in pursuit of different goals. We catalog a book primarily to describe a physical object; normal cataloging does so to tell what is in it and where it is on the shelf.

The one thing that seems clear to me from all this is that we are on the fringes of the library world. Our first concern is the book, not information. Asking questions is more important than answering them. We serve history, not people. With these different priorities, it seems unlikely we will ever be anywhere else but on the fringes if our present connection with the library profession continues as it is.
Should we not be thinking about another arrangement within which to carry out our work?

In looking around for a "place of our own," it is natural that the two areas with which we share common interests, scholarship and museums, should come to mind. We resemble faculty in that research and writing are properly part of our work. We differ in that the faculty teaches and we care for our collections. I am not proposing that tired red herring "faculty status," which confuses form with substance. On the other hand, a large proportion of us work in universities and have more in common with the faculty than with librarians. Somehow our position within the university ought to reflect this.

One of the most meaningless library sayings is "Libraries are not museums." Meaningless if by museum you mean the modern museum with its educational programs, its research, its publications, and the scholars who are on its staff. Like museums we collect the original object in order to find out more about what it means. Perhaps our place should be somewhere between libraries, museums, and the history profession. We partake of some of the characteristics of each and add to them our own conviction of the importance of something that stands by itself, the book.

Assuming that there are those who can accept the reasoning that led up to the proposal that has just been made, I am sure that they would be quick to point out that as a practical matter it leaves a great deal to be desired, particularly if I were proposing it as grounds for immediate action. Such was not my intention. It would not be appropriate for someone who has become an inactive member of the rare book profession to try to outline what you, who will be carrying on, ought to do in the years to come. However, there are two developments that I feel will have to take place: a more closely knit structure for those in rare books and a looser structure in the organization of the library profession. These are hardly original observations, but before closing I would like to make a few comments about them.

Work with rare books as a professional activity stands on its own foundation. It is 


\section{Tailored to meet the ne
library and information LIBRARY LTT

\section{Sample Entry}

"The definitive index in the field." AMERICAN REFERENCE BOOKS QUARTERLY LIBRARY LITERATURE maintains its reputation as the "definitive index" to significant information published on library and information science by reflecting the latest developments and trends in a rapidly evolving field. American, foreign, and international library periodicals, selected state library journals, monographs, non-library journals, conference proceedings, films, filmstrips, pamphlets, microforms, and library school research papers are indexed to provide librarians, library administrators, and other information professionals with access to information on topics crucial to the operation of school, public, professional, and university libraries.

\section{Increased coverage of current information}

Starting with the April, 1984 issue of LIBRARY LITERATURE, $13 \mathrm{key}$ periodicals have been added to the roster of journals indexed. LIBRARY LITERATURE indexes 189 journals and more than 600 monographs each year on such current topics of concern as:

Automation * Censorship * Public Relations * Government Aid * National and International Libraries * Care of Materials $\star$ Copyright Legislation * Personnel Selection and Management * Library Associations * Information Brokers

Thorough and easy to use, LIBRARY LITERATURE offers:

* a single-alphabet subject-author index.

* extensive cross-referencing.

* articles indexed under specific. current library and information science headings to expedite searches.

$\star$ analytic indexing of conference proceedings and collected works.

$\star$ title translations of foreign language materials.

^ complete bibliographic data - title, author, name of periodical, paging, date, and other descriptive information, such as bibliographies, illustrations, and charts.

^ a separate author-title listing of citations to reviews of books on library science.

* a checklist of monographs cited for the first time, given in paper issues only.

^ complete publication data for each of the journals indexed.

$\star$ announcements of appointments and obituaries for figures in the library community.

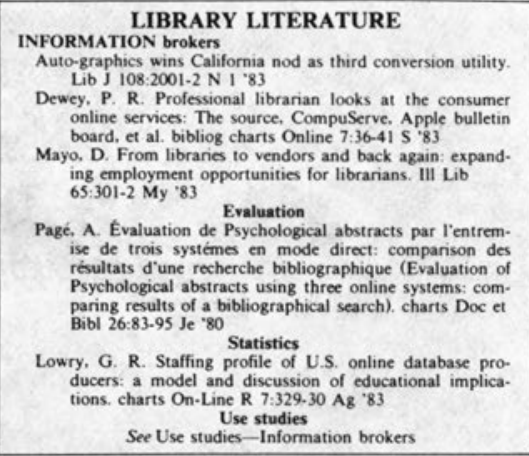

\section{To Order}

A subscription to LIBRARY

LITERATURE brings your library six paperbound issues published in February, April, June, August, October, and December, and a permanent annual clothbound cumulation available in the summer following the indexing year. This index is sold on the service basis. To receive a free, no-obligation price quotation, fill out and return the coupon below.

\section{THE H.W.WILSON COMPANY}

950 University Avenue, Bronx, NY 10452

$\square$ Please send me a no-obligation price quotation on a subscription to LIBRARY LITERATURE.

Our expenditures for books (exclusive of periodicals and binding) for the last three fiscal years have been:
$19 \$$
$; 19 \$$ $19 \$$ ;Total: \$ Average: $\$$

Name Title

Library

Address 


\section{AN}
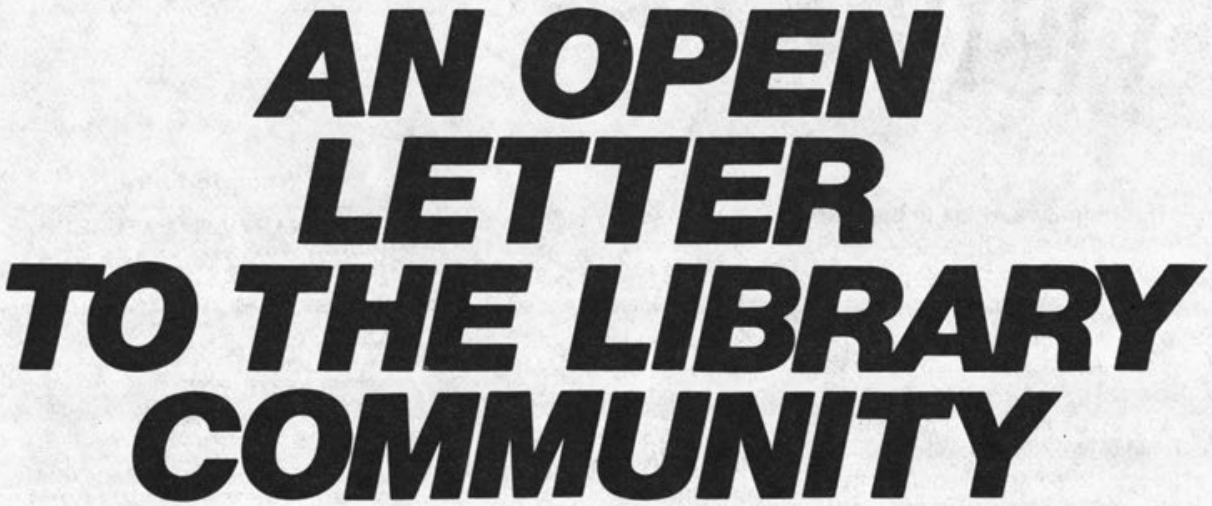

he essential characteristics of society in the information age are instant availability of news and access to the gargantuan amount of information.

The information age is here, but we have just begun to take advantage of the transformation, or even explore the opportunities available to us.

How does a library participate effectively in the information age? How does a library remain as one of the primary stakeholders of information?

We can't depend on "business as usual." In the absence of a national consensus for libraries, we have become overdependent upon past concepts of what a library is supposed to do, and the role a library is supposed to play in society.

The absence of a new role and a new vision for libraries leaves the community with no visible reasons why libraries should increase their budgets, be upgraded and remain the guardians of information.

Libraries can't accept a no-growth future - a future, where their importance fades away just as the typewriter has given way to the word processor.

We can't accept the weakening of the libraries' role in the community, the disintegration to second-rate information providers or the redistribution of information access to the wealthy or advantaged.

We must guarantee that every person has equal opportunity to access information, equal access to the retrieval of information, and equal access to the use of information.

The idea that the future holds less promise than the past for libraries is unacceptable. 
The best insurance against that happening is community demand for the library to play a dominant role in the future. It requires that libraries illuminate the future by becoming more relevant and of greater service and importance to the community.

What do we need?

- New vision...expanded charter

- New ideals and ideas

- New technology (patron access)

- New approaches to meeting the community

- Imaginative leadership

- Dynamism

- Creativity

To identify with the role of libraries in the future, it is necessary to think about it, to visualize it, and to bring that visualization to fruition.

Data Phase is committed to help invest in, implement, and create demand for a new realization and relevancy of the libraries' capabilities and role in society. Data Phase is committed to enhancing the libraries' role in society making sure that there is equal information access, learning opportunities, and technological dissemination, to everyone in the community, not just the privileged few.

Democracy is based on information access for all, information liberty, and information transference. We intend to play whatever role we can to guarantee that the library community comes to the forefront and is on the leading edge of the information age.

We don't mean this to be the last word on the subject, or even the first word. It is our desire to initiate a dialogue. We would like to know whatever people would like to say.

We value your ideas and your partnership. We intend to use this space in the future to publish the responses we receive so that we can continue the dialogue.

Please address your correspondence to Steve Weiss, Senior Vice-President, Data Phase Corporation, 9000 West 67th Street, Shawnee Mission, Kansas, 66202.

We look forward to hearing from you.

\section{$\underset{\text { Data Phase }}{ }$}




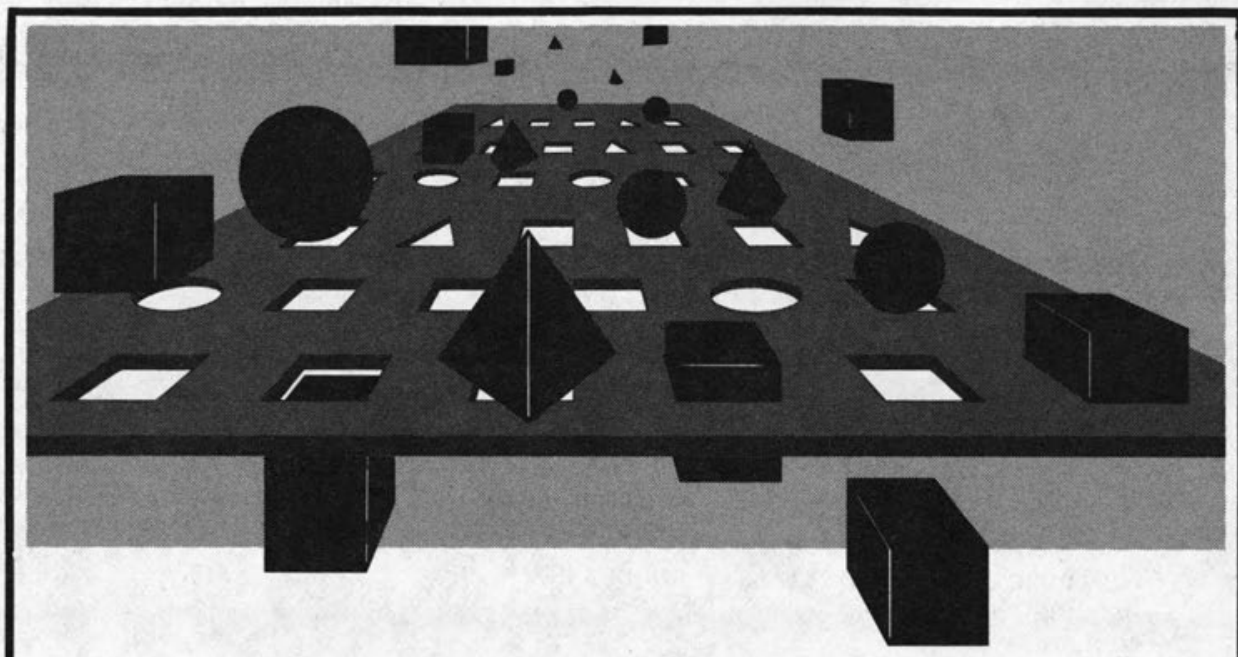

\section{TO GET THE BEST FITTING APPROVAL PROGRAM...}

\section{START WITH THE LARGEST SELECTION}

The diverse disciplinary demands of collection development require the Approval Program with the most comprehensive title coverage. Each year, our Approval Program identifies over 35,000 titles-10,000 more than any other program. Notification slip orders retain full service privileges and our discounts are the best available. Automatic management reports are issued regularly, and no program service charges are ever added.

For details, contact the Sales Department of the division nearest you. 
related to, but different from, conventional librarianship. In our attitude toward ourselves and our work, we must make it clear that dedication to books and the fields of study they represent are as important as the library profession's dedication to information and to service. Our position cannot be that of a supplicant seeking permission to do the things we know need to be done. Rather, having decided what ought to be done, we should go ahead and do them. Consultation is essential if both sides are to benefit because we will always have much in common, but contact should occur only when it is to our mutual benefit. Such an approach may, and probably does, seem arrogant. But it is essential if we are to be seen in the world beyond libraries as a force in our own right. It is to the larger world that we must, in the end, address ourselves if we are to establish what we are doing as truly viable.

Scattered as our resources are in terms of the kinds of books we deal with, the administrative structures under which we live, it is obvious that nothing is to be gained by advancing along a broad front. Instead, the process should be a series of local skirmishes, each of which will deal with individual and local matters. But these must be done with a common sense of unity in our dedication to a common goal.

We already have a number of resources that, if drawn together effectively, can assist. Bibliography, in the largest sense of that word, provides a growing scholarly and academic base. Journals, such as the Papers of the Bibliographical Society of America and Printing History, published by the American Printing History Association, are among many periodicals devoted to aspects of our subject. Those two societies are only two of many organizations that share our interests. Others include book collectors' clubs, Friends organizations, and antiquarian booksellers' organizations. These and other elements need to be connected in a way that will enable them to forcefully help further our interests.

What has just been said may seem antagonistic and combative. A closer look at the library profession today suggests an unsettled state. The explosion of information, the increasing complexity in the ways it is created, stored, and communicated has drastically modified the function that used to be associated primarily with libraries. They no longer occupy the central place they once did. The concept of one central clearinghouse for all library matters is breaking up. As has been true of historical scholarship for some time, we are in a period of specialization, but one in which the specialties work across conventional boundaries to work with other specialties without going back to some central authority for its endorsement. Fluidity is the key to the future. Each element must be freer to make its own decisions about professional education, career goals, and conditions under which work is carried out. The best analogy I can think of in trying to see what the future might hold is what happened to the British Empire.

During the seventeenth and most of the eighteenth century, it was assumed that the mother country and the colonies shared the same interests. Colonial wars and isolated disputes suggested some differences, but it was felt best to leave the power to govern in the hands of the king and Parliament. All went well until 1760, when Britain found herself coping with an enlarged empire with a system of government whose primary interest was, and would continue to be, the United Kingdom. Initially the people in Westminister did not grasp their inadequacy and attempted to treat the original thirteen colonies as if nothing had changed. A great deal had changed during the 175 years since Englishmen first began to occupy this continent. After much agonizing and soul-searching, a group of strong-minded leaders were able to convince enough people to try to go it alone. The decision by Britain to resist this by force of arms was not one agreed to by all Englishmen. There was a vocal element, both in and out of Parliament, which argued that the colonies should be turned loose. But unlike the arguments used by the colonists, theirs had little to do with theories of government. Instead they took the position that the colonies caused more trouble than 
they were worth, and, if given their independence, Britain stood to make more money out of them, which in fact turned out to be the case. Having learned from this mistake, Britain evolved during the next century into the British Commonwealth of Nations, a system so flexible and so decentralized that each part of the empire was allowed to develop in its own way. At the same time, the remaining connections are something more than a matter of form. The attachment to the crown has allowed the former colonies and the United Kingdom to continue the advantages of connection as long as they are useful. It seems to me that this provides a reasonable model that deserves to be looked at as the world of librarianship and the world of rare books begin to make ar- rangements for the future.

I would like to close by coming back to the question posed by my title, Are librarians enemies of books? The answer is clearly no. To the library profession, books are incidental, their first responsibility is the control of information. As for being "enemies," both Blades and my father misused the word. The desire to injure or to do something harmful is necessary before one can become an enemy. In no way can these words be applied to a profession as honorable as librarianship, either in 1937 or today. If books have an enemy, at all, it is change. It is change we are dealing with, and it is up to us to see that books not only do not suffer, but rather that in this new environment they flourish as they have never before.

\section{REFERENCES AND NOTES}

1. The two question marks were used on impulse. It was not until after the paper had been delivered that I discovered among my reprints a short piece by my old friend Rudolf Hirsch using only one question mark: The Rub-Off 12, no.3 (May-June 1961), published by the Art Guild Bindry, Cincinnati, Ohio.

2. The Library Quarterly 7:317-31 (1937). The offprint was reprinted five times.

3. Louis Round Wilson, 1876-1979, at the time the dean of the Graduate Library School, University of Chicago.

4. London: Trübner and Co., 1880. Blades lists nine enemies to which Adams added a tenth.

5. Archibald Cary Coolidge, 1866-1928, director of the University Library, Harvard University, 1910-28. It is worth noting that he was omitted from the Dictionary of American Library Biography (1978). For a full account of his achievements see: William Bentinck-Smith, Building a Great Library: The Coolidge Years at Harvard (Cambridge: Harvard University Library, 1976).

6. Located at Madison near 58 th, it was a popular gathering place for book people working in and around the New York Public Library. 